\title{
Letter to the Editor regarding "Hemiarthroplasty compared to total hip arthroplasty for the treatment of femoral neck fractures: a systematic review and meta-analysis"
}

\author{
Qiujiang $\mathrm{Li}^{1,2+}$, Xingxia Long ${ }^{3+}$, Yinbin Wang ${ }^{2}$, Xiaocheng Jiang ${ }^{1,2}$ and Lijun Cai ${ }^{2^{*}}$
}

\section{Dear Editor:}

We read with great interest the meta-analysis by $\mathrm{Li}$ et al. [1] entitled "Hemiarthroplasty compared to total hip arthroplasty for the treatment of femoral neck fractures: a systematic review and metaanalysis." We congratulate the authors for publishing their study in this journal. Yet upon review of this article, there are serious issues that nullify the conclusions. We seek certain clarifications from the author.

Firstly, the author has extensively searched the published literature through the electronic database (Cochrane, PubMed, and Embase databases), but these databases do not seem to be sufficient to retrieve all eligible studies. Similar results have also been reported in other studies in China, while Chineselanguage studies met the inclusion criteria and the author is a Chinese, so some Chinese databases (such as Wan Fang Data, CNKI databases, Vip Journal Integration Platform (VJIP), and Chinese BioMedical databases) should also be included, which may contribute to a more comprehensive collection of qualified studies.

Secondly, it is general that RCTs and observational studies cannot be combined unless the results are related to the harmful/adverse effects of the intervention as described in the Cochrane Handbook for Systematic Reviews [2]. Therefore, it is a methodological error to combine RCTs with cohort studies in the meta-analysis. A better solution is to make a subgroup analysis of RCTs and cohort studies.

Thirdly, only two RCT studies were included in this meta-analysis, which makes it difficult to ensure data of relatively high quality. A more serious problem is that it was not possible to include all articles published before August 2019, especially some highquality RCT studies. As far as we know, five RCTs [3-7] and one CCT [8] studies were published before the deadline but were not included. As a supplement, we would like to provide more information about these six articles. The studies were eligible according to the authors' inclusion criteria, and they are very helpful in making strong conclusions. Details of these six studies are shown in Table 1.

Fourthly, it was obvious that the two literatures $[9,10]$ are published by the same lead author. The authors repeatedly extracted data from both literatures for analysis, which could lead to erroneous conclusions and mislead clinical practice. Therefore, if several articles were published in the same trial, the study with the most relevant information or the longest follow-up period may be the most appropriate.

\footnotetext{
* Correspondence: cqsgklqj@163.com

${ }^{\dagger}$ Qiujiang Li and Xingxia Long contributed equally to this manuscript.

${ }^{2}$ Department of Orthopedics, People's Hospital of Ningxia Hui Autonomous

Region, No. 56, Zhengyuan Street, Yinchuan 750002, Ningxia, China

Full list of author information is available at the end of the article
} 
Table 1 Six studies not included in the Li et al. [1] systematic review

\begin{tabular}{|c|c|c|c|c|c|c|c|c|c|}
\hline \multirow[t]{2}{*}{ Study } & \multirow[t]{2}{*}{ Year } & \multicolumn{2}{|c|}{$\begin{array}{l}\text { No. of } \\
\text { patients }\end{array}$} & \multicolumn{2}{|c|}{$\begin{array}{l}\text { Age } \\
\text { (years) }\end{array}$} & \multicolumn{2}{|c|}{ Gender } & \multirow[t]{2}{*}{ Mean follow-up duration (months) } & \multirow[t]{2}{*}{$\begin{array}{l}\text { Study } \\
\text { design }\end{array}$} \\
\hline & & HA & TKA & HA & TKA & HA & TKA & & \\
\hline Tol et al. [3] and van den Bekerom et al. [5] & 2017 and 2010 & 137 & 115 & 80.3 & 82.1 & $115 F$ & $90 \mathrm{~F}$ & 144 & $\mathrm{RCT}$ \\
\hline Avery et al. [4] and Baker et al. [7] & 2011 and 2006 & 41 & 40 & 75.8 & 74.2 & NA & NA & 108 & $\mathrm{RCT}$ \\
\hline Keating et al. [6] & 2006 & 69 & 69 & 75.0 & 75.2 & $54 \mathrm{~F}$ & $52 \mathrm{~F}$ & 24 & $\mathrm{RCT}$ \\
\hline Mouzopoulos et al. [8] & 2008 & 34 & 37 & 74.2 & 73.1 & $24 \mathrm{~F}$ & $28 \mathrm{~F}$ & 60 & CCT \\
\hline
\end{tabular}

$R C T$ randomized controlled trial, CCT controlled clinical trial, NA not available, HA hemiarthroplasty, TKA total hip arthroplasty

Fifthly, the full results of the meta-analysis show a high degree of heterogeneity and sensitivity analysis was lacking to further analyze the sources of heterogeneity; thus, it weakens the credibility of the results.

Finally, all of the above points may lead readers to question the reliability of the conclusions. Therefore, we hope that the authors will correct the relevant problems pointed out, which will only serve to benefit the research community at large.

\section{Acknowledgements}

None.

\section{Declarations}

\section{Authors' contributions}

$Q L$ and $X L$ wrote this manuscript; $Y W, X J$, and $L C$ reviewed the selected studies in Li et al.'s review. All authors read and approved the final manuscript.

\section{Funding}

None.

\section{Availability of data and materials \\ Not applicable.}

Ethics approval and consent to participate

Not applicable.

\section{Consent for publication}

Not applicable.

\section{Competing interests}

The authors declare that they have no competing interests.

\section{Author details}

${ }^{1}$ Graduate School of Ningxia Medical University, Yinchuan, Ningxia, China. ${ }^{2}$ Department of Orthopedics, People's Hospital of Ningxia Hui Autonomous Region, No. 56, Zhengyuan Street, Yinchuan 750002, Ningxia, China. ${ }^{3}$ West China Hospital, Sichuan University, Chengdu, Sichuan, China.

Received: 29 March 2021 Accepted: 17 May 2021

Published online: 20 May 2021

\section{References}

1. Li X, Luo J. Hemiarthroplasty compared to total hip arthroplasty for the treatment of femoral neck fractures: a systematic review and meta-analysis. J Orthop Surg Res. 2021;16(1):172. https://doi.org/10.1186/s13018-020-021 86-4.

2. Cumpston M, Li T, Page MJ, Chandler J, Welch VA, Higgins JP, et al. Updated guidance for trusted systematic reviews: a new edition of the Cochrane Handbook for Systematic Reviews of Interventions. Cochrane Database Syst Rev. 2019;10:D142.
3. Tol MCJM, van den Bekerom MPJ, Sierevelt IN, Hilverdink EF, Raaymakers ELFB, Goslings JC. Hemiarthroplasty or total hip arthroplasty for the treatment of a displaced intracapsular fracture in active elderly patients 12year follow-up of randomised trial. Bone Jjoint J. 2017;99B(2):250-4.

4. Avery PP, Baker RP, Walton MJ, Rooker JC, Squires B, Gargan MF, et al. Total hip replacement and hemiarthroplasty in mobile, independent patients with a displaced intracapsular fracture of the femoral neck: a seven- to tenyear follow-up report of a prospective randomised controlled trial. J Bone Joint Surg Br Vol. 2011;93(8):1045.

5. van den Bekerom MP, Hilverdink EF, Sierevelt IN, Reuling EM, Schnater JM,

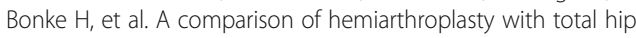
replacement for displaced intracapsular fracture of the femoral neck: a randomised controlled multicentre trial in patients aged 70 years and over. J Bone Joint Surg (Br). 2010;92(10):1422-8.

6. Keating JF, Grant A, Masson M, Scott NW, Forbes JF. Randomized comparison of reduction and fixation, bipolar hemiarthroplasty, and total hip arthroplasty. Treatment of displaced intracapsular hip fractures in healthy older patients. J Bone Joint Surg (Am Vol). 2006;88(2):249.

7. Baker RP, Squires B, Gargan MF, Bannister GC. Total hip arthroplasty and hemiarthroplasty in mobile, independent patients with a displaced intracapsular fracture of the femoral neck. A randomized, controlled trial. J Bone Joint Surg Am. 2006;88(12):2583-9. https://doi.org/10.2106/00004623-2 00612000-00004.

8. Mouzopoulos G, Stamatakos M, Arabatzi H, Vasiliadis G, Batanis G, Tsembeli A, et al. The four-year functional result after a displaced subcapital hip fracture treated with three different surgical options. Int Orthop. 2008;32(3): 367-73. https://doi.org/10.1007/s00264-007-0321-1.

9. Mukka S, Sjoholm P, Chammout G, Kelly-Pettersson P, Sayed-Noor AS, Skoldenberg O. External validity of the HOPE-trial: hemiarthroplasty compared with total hip arthroplasty for displaced femoral neck fractures in octogenarians. JB JS Open Access. 2019;4(2):e61.

10. Chammout G, Kelly-Pettersson P, Hedbeck CJ, Stark A, Mukka S, Skoldenberg O. HOPE-Trial: hemiarthroplasty compared with total hip arthroplasty for displaced femoral neck fractures in octogenarians: a randomized controlled trial. JB JS Open Access. 2019;4(2):e59.

\section{Publisher's Note}

Springer Nature remains neutral with regard to jurisdictional claims in published maps and institutional affiliations.

Ready to submit your research? Choose BMC and benefit from:

- fast, convenient online submission

- thorough peer review by experienced researchers in your field

- rapid publication on acceptance

- support for research data, including large and complex data types

- gold Open Access which fosters wider collaboration and increased citations

- maximum visibility for your research: over $100 \mathrm{M}$ website views per year

At $\mathrm{BMC}$, research is always in progress.

Learn more biomedcentral.com/submissions 